\title{
Intestinal malabsorption in infants with histiocytosis $\mathrm{X}$
}

\author{
J. W. KEELING and J. T. HARRIES \\ From The Hospital for Sick Children, Great Ormond Street, and \\ the Institute of Child Health, London
}

\begin{abstract}
Keeling, J. W., and Harries, J. T. (1973). Archives of Disease in Childhood, 48, 350. Intestinal malabsorption in infants with histiocytosis $X$. An infant with histiocytosis $\mathrm{X}$ had unequivocal evidence of intestinal malabsorption which was associated with histiocytic infiltration of the small intestine. 11 other fatal cases where histological material from the gastrointestinal tract was available are reviewed.
\end{abstract}

The acute form of histiocytosis $\mathrm{X}$ usually presents in infancy: weight loss is common, and there is a high mortality (Oberman, 1961; Lucaya, 1971). Though diarrhoea and histological involvement of the gastrointestinal tract have each been reported (Havard, Rather, and Faber, 1950; Batson et al., 1955; Avery, McAfee, and Guild, 1957; Oberman, 1961), the causal relation between the infiltrative process and the diarrhoea has received little attention (Feinberg and Lester, 1958). To our knowledge intestinal function has not previously been investigated in infants with this condition.

\section{Case report}

A girl (Case 1) was born at term to healthy unrelated parents after an uncomplicated pregnancy, and weighed $3.4 \mathrm{~kg}$; there was no relevant family history. A generalized skin eruption was noticed soon after birth and, because of a persistent cough, food refusal, and weight loss, she was admitted to another hospital at 6 weeks when she weighed $3.3 \mathrm{~kg}$; she was noted to pass loose, frequent stools. The cough and diarrhoea persisted, and she was transferred to The Hospital for Sick Children at 8 weeks. Her weight was $3.25 \mathrm{~kg}(<3$ rd centile), there was a widespread erythematous exfoliating skin eruption, the axillary and inguinal lymph nodes were firm and moderately enlarged, râles were audible over both lung fields. and both liver and spleen were palpable $1 \mathrm{~cm}$ below the costal margins.

Investigations. Chest $x$-ray showed extensive patchy consolidation of left lung and right upper zone, but no skeletal abnormalities. Faecal fat excretion over 4 days was $7 \cdot 5,7 \cdot 6,5 \cdot 4,3 \cdot 2 \mathrm{~g} /$ day (mean $5 \cdot 9$ ); examination of stool sugar concentrations $(\mathrm{mg} / 100 \mathrm{~g}$ faeces) by paper chromatography: lactose 400 , galactose 200 , glucose 320 , fructose 30 (normal usually $<10$ ); urine sugar concentrations (mg/100 ml): lactose 200,

Received 25 September 1972. galactose 40 , glucose 60 , sucrose 80 , fructose 60 (normal usually 20); serum vitamin E $0.24 \mathrm{mg} / 100 \mathrm{ml}$ (normal 0.5 to 1.5 ), RBC peroxide haemolysis $49 \%$ (normal 5 ); serum cholesterol and triglycerides 70 and $40 \mathrm{mg} / 100 \mathrm{ml}$, respectively; total serum proteins $6.6 \mathrm{~g} / 100 \mathrm{ml}$, serum albumin (immunochemical) $3.0 \mathrm{~g} / 100 \mathrm{ml}$, electrophoresis normal. The following investigations were normal: haemoglobin, white blood count, and platelets; repeated examination of stools for ova, cysts, giardia, and enteropathogenic bacteria; plasma calcium: urea, and electrolytes; serum rubella antibodies, immunoglobulins, transaminases, and bilirubin; urine amino acids, microscopy, and culture; WR, blood glucose, examination of CSF, sweat electrolytes, and cytomegalovirus complement-fixation test.

Lymph node biopsy: destruction of normal architecture, infiltration by sheets of large pale histiocytes with vacuolated nuclei; numerous mitotic figures among infiltrating cells. Skin biopsy: normal epidermis, dense histiocytic infiltration of upper dermis (Fig. 1).

Progress. She continued to pass 3 to 8 loose stools per day; because of the increased faecal excretion of fat and sugars, a low fat and disaccharide-free diet supplemented by medium chain triglycerides was introduced and resulted in an improvement in stool consistency and frequency. 3 weeks after admission, total serum proteins and serum albumin had fallen from 6.6 to $4.4 \mathrm{~g} / 100 \mathrm{ml}$, and 3.0 to $2.5 \mathrm{~g} / 100 \mathrm{ml}$, respectively.

Treatment with vinblastine sulphate and corticosteroids resulted in improvement of the skin lesions and a reduction in the size of the enlarged lymph nodes. The recurrent and severe chest infection proved difficult to control and she died 7 weeks after admission; a few days before death Esch. coli 0114 was cultured from a stool.

Necropsy findings. An emaciated Caucasian female infant with scaly skin. Lungs bulky and pink with prominent interlobular septa and focal haemorrhages. 


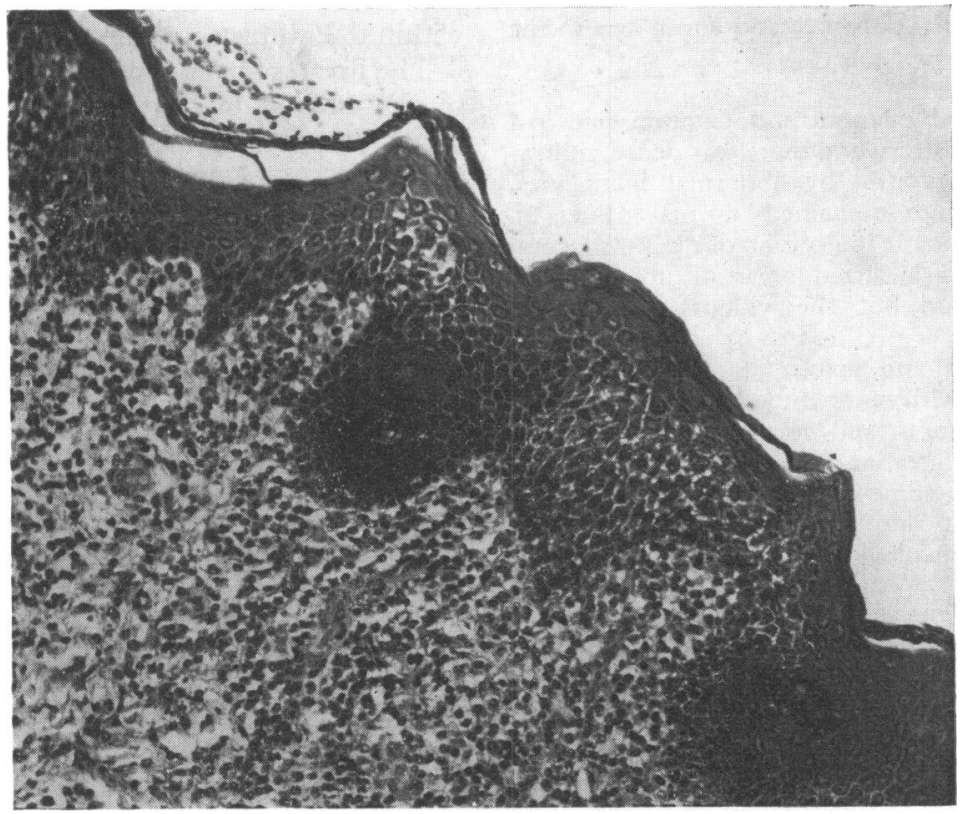

FIG. 1.-Skin biopsy of Case 1 showing dense histiocytic infiltration of upper dermis. (H. and E. $\times 27$.

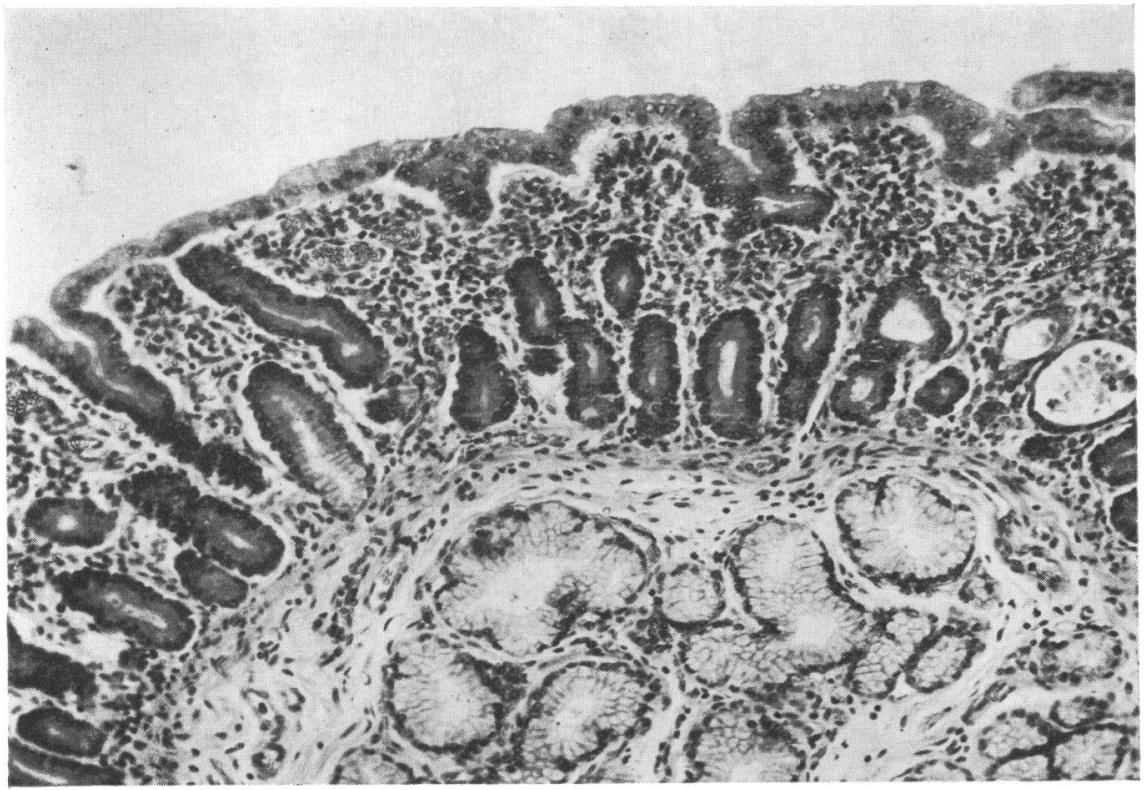

FIG. 2. - Jejunum of Case 1 showing loss of normal villous pattern with normal surface epithelial cells and histiocytic infiltration of the lamina propria. (H. and $E . \times 35$. 
Liver and spleen enlarged; large cream coloured lymph nodes present around the trachea and aorta, and in the mesentery.

Histology. The duodenum and jejunum had lost their normal villous pattern and there was dense infiltration of the lamina propria by abnormal histiocytes, though the epithelium remained normal (Fig. 2). There was focal histiocytic infiltration of the submucosa. The ileum contained localized areas of mucosal and submucosal infiltration but the villous pattern was normal.

The lymph nodes and spleen were infiltrated by sheets of histiocytes with marked nuclear pleomorphism and many mitotic figures, and normal architecture was lost. Histiocytic infiltration was extensive in both lungs, was present in some hepatic portal areas and in the upper dermis of skin from the abdominal wall. The pancreas was histologically normal.

\section{Review of other patients}

The site of involvement of the gastrointestinal tract by the disease process and its distribution within the wall is shown in the Table.

The ileum was most commonly affected, followed by the duodenum and jejunum. Within the wall, the lamina propria was most often involved, either alone or accompanied by infiltration of other parts of the wall. The infiltration consisted of histiocytes which showed marked cellular and nuclear pleomorphism, multinucleate giant cells were present in some cases (Fig. 3), and mitotic activity was marked in the infiltrating cells. When present, serosal involvement was accompanied by local and generalized dilatation of lymphatics (Fig. 3). Villous pattern and epithelium was normal in all cases. The pancreas was histologically normal in all cases. Examination of the liver showed scanty histiocytic infiltration of the portal tracts in 6 cases, and this was more marked in 1 case; in the other cases the liver was not involved. There was no increased fibrosis or loss of normal hepatic architecture in any of the cases.

TABLE

Sites of involvement of gastrointestinal tract in infants with histiocytosis $X$

\begin{tabular}{|c|c|c|c|c|c|c|c|c|c|c|c|c|}
\hline & \multicolumn{7}{|c|}{ Diarrhoea } & \multicolumn{5}{|c|}{ No diarrhoea } \\
\hline Case no. & 1 & 2 & 3 & 4 & 5 & 6 & 7 & 8 & 9 & 10 & 11 & 12 \\
\hline $\begin{array}{l}\text { Oesophagus } \\
\text { Epithelium } \\
\text { Submucosa } \\
\text { Muscle } \\
\text { Serosa }\end{array}$ & & & + & & & & & & & $\begin{array}{l}++ \\
++ \\
++\end{array}$ & & \\
\hline $\begin{array}{l}\text { Stomach } \\
\text { Mucosa } \\
\text { Submucosa } \\
\text { Muscle } \\
\text { Serosa }\end{array}$ & & & & & & & & & & + & & \\
\hline $\begin{array}{l}\text { Duodenum } \\
\text { Mucosa } \\
\text { Submucosa } \\
\text { Muscle } \\
\text { Serosa }\end{array}$ & +++ & & + & & & ++ & & & $\begin{array}{l}++ \\
++\end{array}$ & + & & \\
\hline $\begin{array}{l}\text { Jejunum } \\
\text { Mucosa } \\
\text { Submucosa } \\
\text { Muscle } \\
\text { Serosa }\end{array}$ & $\begin{array}{l}+++ \\
+++\end{array}$ & & & & & ++ & & & ++ & $\begin{array}{c}+ \\
+++\end{array}$ & & \\
\hline $\begin{array}{l}\text { Ileum } \\
\text { Mucosa } \\
\text { Submucosa } \\
\text { Muscle } \\
\text { Serosa }\end{array}$ & $\begin{array}{l}++ \\
++\end{array}$ & & $\begin{array}{l}+ \\
++\end{array}$ & + & & $\begin{array}{l}++ \\
++\end{array}$ & & & ++ & $\begin{array}{l}++ \\
++\end{array}$ & & \\
\hline $\begin{array}{l}\text { Colon } \\
\text { Mucosa } \\
\text { Submucosa } \\
\text { Muscle } \\
\text { Serosa }\end{array}$ & & & ++ & & & & + & & & & & \\
\hline
\end{tabular}

+++ , dense histiocytic infiltration; ++ , moderate histocytic infiltration; + , slight histiocytic infiltration. 


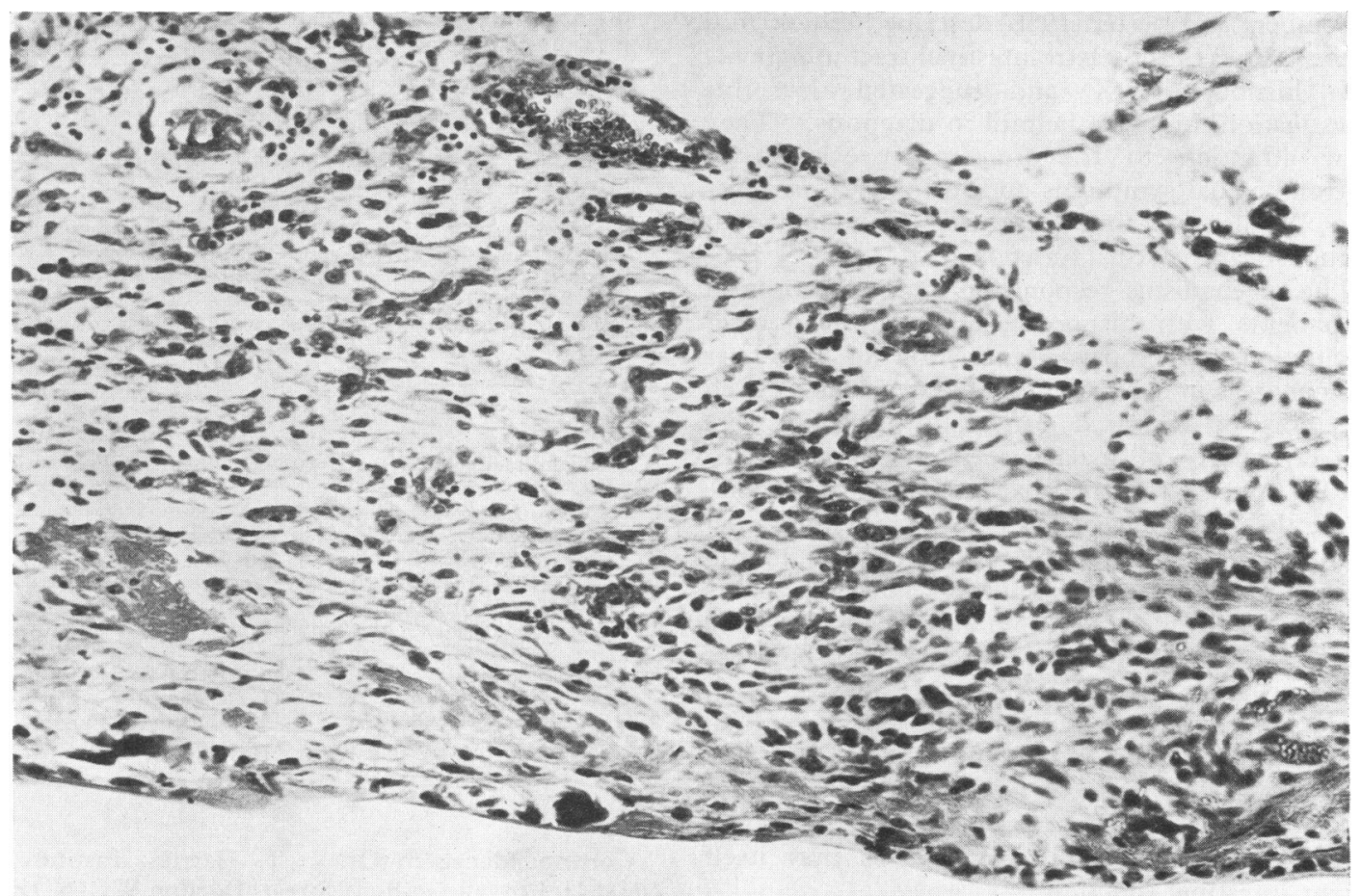

FIG. 3.-Ileum showing histiocytic infiltration of the serosa and prominent multinucleate giant cells. Lymphatics are dilated. $(H$. and $E . \times 136$.

The ages of the patients at the time of death varied from 3 to 54 months (mean $12 \cdot 3$ months). 7 patients developed diarrhoea during the course of their illness, the onset of diarrhoea preceding the introduction of corticosteroids and/or cytotoxic agents in each case. The duration of diarrhoea varied from 1 to 3 weeks in 3 patients (Cases 4, 6, and 7), was intermittent in 2 (Cases 2 and 5), and was protracted, lasting for several weeks in Cases 1 and 3. 5 of the 7 patients with diarrhoea had histological involvement of the small intestine and this was most marked in Case 1, the index case.

\section{Discussion}

The tumour-like proliferative disorders of the reticuloendothelial system, Letterer-Siwe, HandSchüller-Christian disease, and eosinophilic granuloma, are considered by many to be manifestations of a clinicopathological spectrum designated histiocytosis X (Lichtenstein, 1964). The clinical and pathological features of the 12 patients reported are those of acute, disseminated histiocytosis $\mathrm{X}$
(Letterer-Siwe's syndrome) where multisystem involvement is usual.

In the index case the mean faecal fat was $5.9 \mathrm{~g} /$ day, which is greater than the accepted upper limit of normal ( $4.5 \mathrm{~g} /$ day) in children (Anderson, 1966); steatorrhoea was present despite an inadequate dietary intake due to food refusal, and was therefore probably an underestimate of the actual degree of malabsorption present. The reduced serum levels of cholesterol and vitamin $\mathrm{E}$ were consistent with impaired absorption of other lipid-soluble substances. The raised faecal and urine sugar concentrations coupled with the improvement which followed withdrawal of disaccharides from the diet, indicate defective intestinal handling of sugars. Impaired intestinal function may have contributed to the fall in serum protein levels.

Of the 12 patients, 7 had a history of loose, frequent stools for varying periods; in these patients impaired intestinal handling of water and electrolytes may have been accompanied by malabsorption of other dietary substances. 
Feinberg and Lester (1958) described radiological abnormalities of the gastrointestinal tract in patients with histiocytosis $\mathrm{X}$, and suggested that this investigation might be helpful in diagnosis. They drew attention to the frequent association of gastrointestinal symptoms and histological involvement of the gastrointestinal tract in infancy, but did not study intestinal function.

The mechanisms responsible for malabsorption in patients with histiocytosis $\mathrm{X}$ require further elucidation. Necropsy examination of the liver and pancreas in our patients suggested that reduced bile flow or impaired pancreatic function were unlikely causes of malabsorption. Villous architecture appeared normal except in the index case where the abnormal villous pattern resembled that seen in coeliac disease; the normal epithelium and the nature of the cellular infiltrate, however, makes this diagnosis unlikely (Rubin and Dobbins, 1965). Mesenteric lymph node involvement with lymphatic obstruction may interfere with absorption of lipids, and bacterial infection of the gastrointestinal tract in such debilitated infants could also cause diarrhoea. The frequent association of diarrhoea and mucosal infiltration by histiocytes, however, suggests that such cellular infiltration may itself impair intestinal function.
We are grateful to Professor O. H. Wolff for permission to publish details of the index case.

\section{REFERENCES}

Anderson, C. M. (1966). Intestinal malabsorption in childhood. Archives of Disease in Childhood, 41, 571.

Avery, M. E., McAfee, J. G., and Guild, H. G. (1957). The course and prognosis of reticuloendotheliosis (eosinophilic granuloma, Schüller-Christian disease, and Letterer-Siwe disease): a study of forty cases. American fournal of Medicine, 22, 636.

Batson, R., Shapiro, J., Christie, A., and Riley, H. D. (1955). Acute nonlipid disseminated reticuloendotheliosis. American fournal of Diseases of Children, 90, 323.

Feinberg, S. B., and Lester, R. G. (1958). Radiological examination of the gastrointestinal tract as an aid to the diagnosis of acute and subacute reticuloendotheliosis. Radiology, 71, 525.

Havard, E., Rather, L. J., and Faber, H. K. (1950). Nonlipoid reticuloendotheliosis (Letterer-Siwe's disease). Pediatrics, 5, 474.

Lichtenstein, L. (1964). Histiocytosis X (eosinophilic granuloma of bone, Letterer-Siwe disease, and Schüller-Christian disease). fournal of Bone and foint Surgery, 46A, 76.

Lucaya, J. (1971). Histiocytosis X. American fournal of Diseases of Children, 121, 289.

Oberman, H. A. (1961). Idiopathic histiocytosis. A clinicopathologic study of $\mathbf{4 0}$ cases and review of the literature on eosinophilic granuloma of bone, Hand-Schüller-Christian disease and Letterer-Siwe disease. Pediatrics, 28, 307.

Rubin, C. E., and Dobbins, W. O. (1965). Peroral biopsy of the small intestine: a review of its diagnostic usefulness. Gastroenterology, 49, 676 .

Correspondence to Dr. J. T. Harries, Institute of Child Health, 30 Guilford Street, London WC1N 1EH. 